\title{
Clinical Application of Pure Titanium for Cast Plate Dentures
}

\author{
Mutsuo YAMAUCHI, Makoto SAKAI and Joji KAWANO \\ First Department of Prosthodontics, Asahi University, School of Dentistry, 1851-1, Hozumi-cho, \\ Motosu-gun, Gifu, 501-02, Japan
}

Received on January 27,1988

Acceptd on Martch 28, 1988

Pure titanium cast plate denture produced by Ohara's titanium casting system were inserted in eight patients. The pure titanium cast plate dentures enabled satisfactory fitness and had good adaptability to the mucosal surface. Furthermore, they are lighter in weight than conventional cast dentures. X-ray examination revealed some casting defects, but these defects were not serious enough to be conducive to damages. Follow-up observation of the patients with these dentures indicated no clinical problems. However, inadequate adhesiveness with resin was a technical problem encountered. Examination of the castability of pure titanium using this system showed that casting in the meshtype wax pattern failed to produce a complete form of mesh, while casting in the plate-type wax patterns produced a complete contour of the plates. X-ray examination of the plate cast, however, revealed some casting defects.

Key words: Pure titanium, Cast plate denture, Clinical application

\section{INTRODUCTION}

Dental application of pure titanium has been increasingly studied in recent years, because of its good properties as a dental casting alloy ${ }^{1-3}$. Basic and clinical studies on cast pure titanium crowns have been undertaken by Ida $e t a l .{ }^{3)}$. However, cast plate dentures of pure titanium have not been studied basically or clinically. A pure titanium casting system is at present commercially available in Japan, and at some commercial laboratories. Also cast plate denture of pure titanium has already been produced for clinical application ${ }^{4}$.

To evaluate the usefulness of pure titanium as a material for cast plate dentures, follow-up examination was carried out in patients fitted with pure titanium cast plate dentures prepared by a commercial casting system to examine clinical problems and problems related to possible casting defects. A basic experiment was also carried out to determine the castability of the system used in this study.

\section{MATERIALS AND METHODS}

\section{Follow-up observation of pure titanium cast plate dentures fitted in patients}

Table 1 shows patients with pure titanium cast plate dentures observed in this study. The pure titanium cast plate dentures used were all prepared using an Ohara's pure titanium casting system for plate denture. Items under observation included denture weight, feeling of denture weight, temperature sensation, masticatory function (pleasantness in chewing), adaptability to the mucosal surface, abnormality of the mucosal membrane under the denture, dye penetration from the finish line, and discoloration of the metal. 
Table 1 Follow-up observation of pure titanium cast plate dentures fitted in patients

\begin{tabular}{c|c|c|c|c}
\hline Subject & Age in years & Prosthesis & Functioning time in months & Denture base resin \\
\hline 1 & 71 & Upper complete denture & 9 & Metadent $^{\dagger}$ \\
\hline \multirow{2}{*}{2} & 65 & Upper partial denture & 10 & Metadent $^{*}$ \\
\cline { 2 - 5 } & & Lower partial denture & 4 & Metadent \\
\hline 3 & 54 & Upper partial denture & 10 & Acron \\
\hline 4 & 71 & Upper complete denture & 10 & Acron \\
\hline 5 & 62 & Upper complete denture & 7 & Acron \\
\hline 6 & 76 & Upper complete denture & 13 & Acron \\
\hline 7 & 51 & Upper complete denture & 3 & Acron \\
\hline 8 & 60 & Upper complete denture & 3 & Acron \\
\hline
\end{tabular}

$\dagger$ : Sun medical Co. Ltd., Osaka, Japan $\quad$ : GC Dental Industry Corp., Tokyo, Japan

Table 2 Casting conditions for pure titanium and $\mathrm{Co}-\mathrm{Cr}$ alloy

\begin{tabular}{c|c|c|c|c}
\hline Metal & Type of investment & $\begin{array}{c}\text { Maximum firing } \\
\text { temperature }\end{array}$ & $\begin{array}{c}\text { Mold temperature } \\
\text { at casting }\end{array}$ & Casting machine \\
\hline Pure titanium* & $\mathrm{MgO} \ddagger$ & $1200^{\circ} \mathrm{C}$ & Room temperature & Titaniumer $\ddagger$ \\
\hline Co-Cr alloy\# & Phosphate bonded ${ }^{\dagger}$ & $800^{\circ} \mathrm{C}$ & $800^{\circ} \mathrm{C}$ & Castmatic $^{\S}$ \\
\hline
\end{tabular}

* : Ohara Co. Ltd., Osaka, Japan

\# : Hi-cobalt, Hi-Dental Service Ltd., Osaka, Japan

$\dagger$ : Tai-best, GC Dental Industry Corp., Tokyo, Japan

¥: Titaniumvest, Ohara Co. Ltd., Osaka, Japan

$\S$ : Type 230, Iwatani Industrial Co. Ltd., Tokyo, Japan

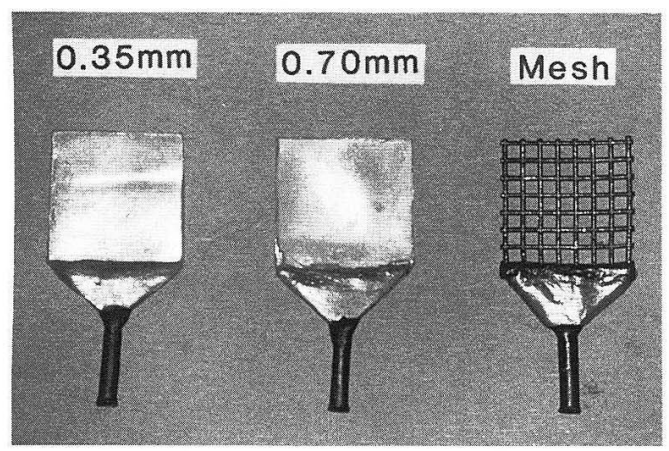

Fig. 1 Wax patterns used in examination of the castability.

\section{Castability}

Castability was examined in three pure titanium cast samples prepared under the casting conditions specified in Table 2 using three kinds of wax patterns (Fig. 1: $20 \times 20 \mathrm{~mm}$ plate 
form with $0.35 \mathrm{~mm}$ thickness, $20 \times 20 \mathrm{~mm}$ plate form with $0.70 \mathrm{~mm}$ thickness and $20 \times 20 \mathrm{~mm}$ mesh form). Three $\mathrm{Co}-\mathrm{Cr}$ alloy cast samples were also prepared in corresponding sizes and with the same casting conditions, and were used for comparison.

$X$-ray inspection of casting defects

The casting defects of dentures fitted in patients and the cast samples prepared for determining the castability were examined using an X-ray instrument for dental casts* with a tube voltage of $80 \mathrm{kVp}$, current of $3 \mathrm{~mA}$ and irradiation time of $0.8 \mathrm{~s}$.

\section{RESULTS AND DISCUSSION}

\section{Observation of dentures}

Table 3 shows the follow-up observation results of the clinical cases and Fig. 2 shows some typical examples. We began application of pure titanium cast plate dentures approximately 14 months ago. Therefore, the use of these dentures had a short history of 7.7 months on the average. Because of it's low specific gravity (4.5), a great benefit is expected when pure titanium is used as a maxillary prosthodontic material ${ }^{11}$. Denture weight used in this study ranged from a minimum of $4.5 \mathrm{~g}$ to maximum of $26.3 \mathrm{~g}$ and the maxillary dentures used had a mean weight of $15.3 \mathrm{~g}$. This weight is comparable to that of conventional resin dentures. Compared to $\mathrm{Co}-\mathrm{Cr}$ and $\mathrm{Ni}-\mathrm{Cr}$ alloys having larger specific gravities than resin, the pure titanium dentures were considerably lighter, and as such, this lower specific gravity is advantageous. All the patients said they were conscious of the light weight of their dentures.

None of the patients complained of unpleasantness in temperature sensation or chewing.

Using white silicone**, the dentures were found to have a satisfactory level of fitness (Fig. 3).

Table 3 Results of follow-up observation

\begin{tabular}{c|c|c|c|c|c|c|c|c}
\hline Subject & $\begin{array}{c}\text { Weight of } \\
\text { denture }\end{array}$ & $\begin{array}{c}\text { Feeling } \\
\text { of } \\
\text { denture } \\
\text { weight }\end{array}$ & $\begin{array}{c}\text { Temperature } \\
\text { sensation }\end{array}$ & $\begin{array}{c}\text { Pleasantness } \\
\text { in chewing }\end{array}$ & Adaptability & $\begin{array}{c}\text { Abnormality } \\
\text { of underlying } \\
\text { tissue }\end{array}$ & $\begin{array}{c}\text { Dye } \\
\text { penetration }\end{array}$ & $\begin{array}{c}\text { Discoloration } \\
\text { of the } \\
\text { metal }\end{array}$ \\
\hline 1 & $18.9 \mathrm{~g}$ & light & fairly good & fairly good & good & none & none & none \\
\hline 2 & $9.3 \mathrm{~g}$ & light & fairly good & fairly good & fairly good & none & observed & none \\
\cline { 2 - 9 } & $4.5 \mathrm{~g}$ & & & & fairly good & none & none & none \\
\hline 3 & $7.4 \mathrm{~g}$ & light & good & good & good & none & observed & yes \\
\hline 5 & $8.5 \mathrm{~g}$ & light & fairly good & fairly good & good & none & none & none \\
\hline 6 & $9.3 \mathrm{~g}$ & light & fairly good & fairly good & fairly good & none & none & none \\
\hline 7 & $24.2 \mathrm{~g}$ & light & good & good & fairly good & none & none & none \\
\hline 8 & $26.3 \mathrm{~g}$ & light & good & good & fairly good & none & none & none \\
\hline
\end{tabular}

* DCX-100 Asahi Roentgen Co., Ltd., Kyoto, Japan

** Fit checker, GC Dental Industry, Corp., Tokyo, Japan 


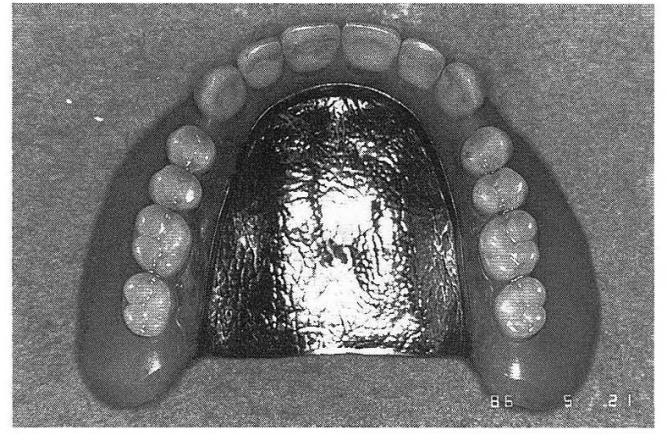

A

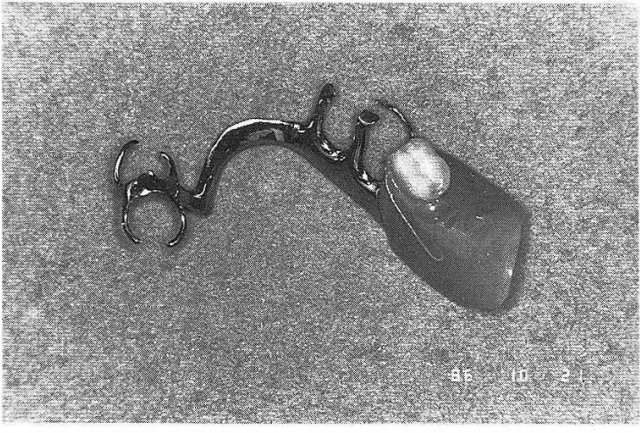

B

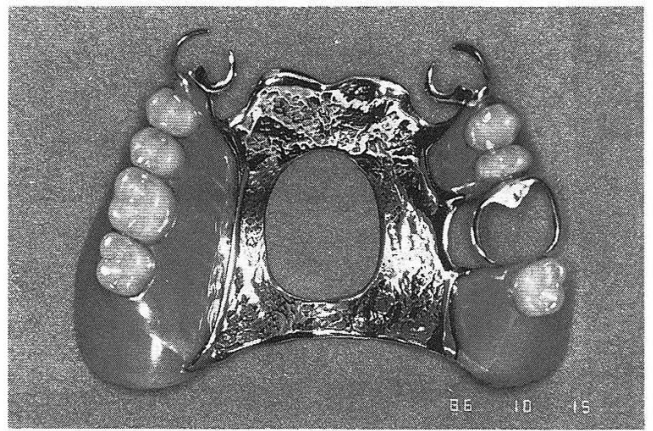

C

Fig. 2 A : an example of the upper complete denture (Case 1), B : an example of the lower partial denture (Case 2) and $\mathrm{C}$ : an example of the upper partial denture (Case 3).

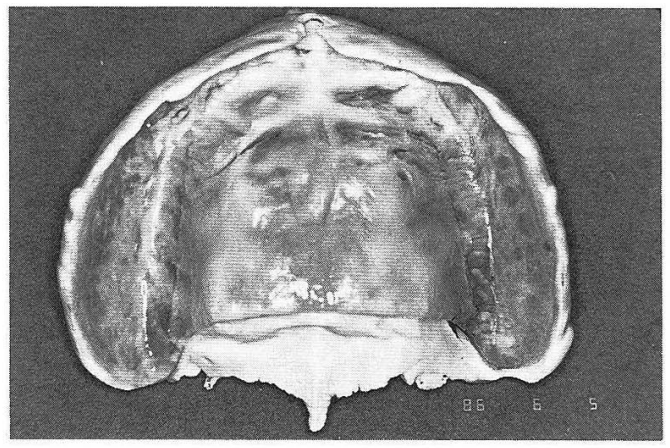

Fig. 3 Fitness test on the mucosal surface in case 1 . Both the resin and cast parts are well fit.

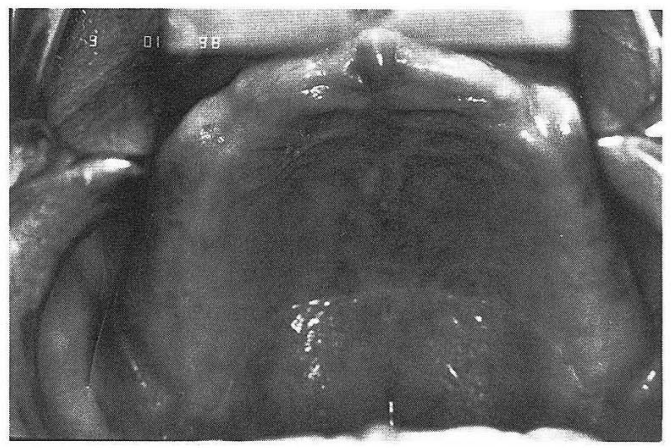

Fig. 4 The mucosal membrane under the denture in case 1 . No abnormalities such as reddening or swelling are visible.

Abnormality of the mucosal membrane under the denture was found in none of the patients (Fig. 4).

Examination of the cleaning condition of the dentures showed denture plaque adhering 


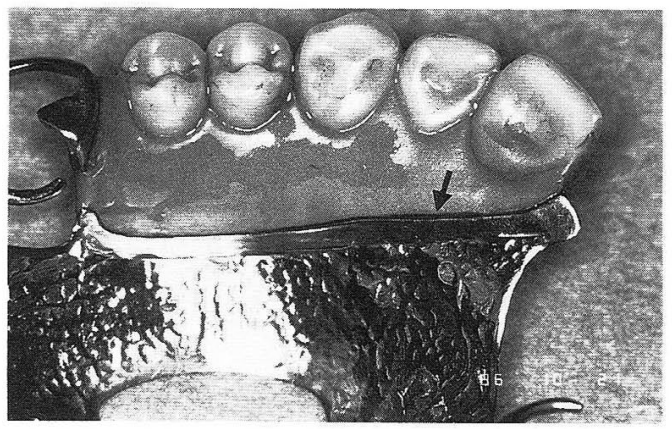

Fig. 5 A case that showed detachment of the base resin and dye penetration from finish line.

\section{PureTi:0.35mm}

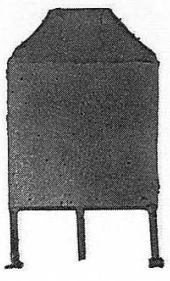

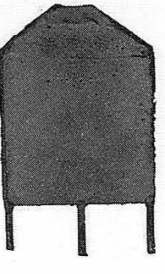

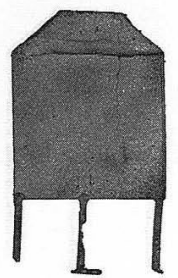

PureTi:0.70mm
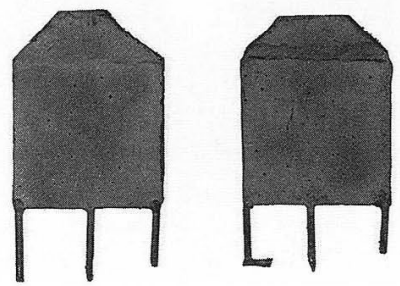

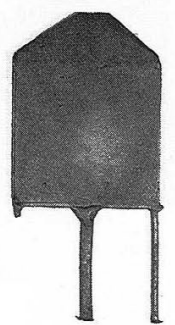

Fig. 6 Casting of pure titanium in the $0.35 \mathrm{~mm}$-thick wax pattern resulted in incomplete casting in some samples, but casting in the $0.70 \mathrm{~mm}$-thick wax pattern produced satisfactory casts.

mostly to the resin base of the denture and rarely to the titanium part.

Dye penetration from the finish line was found in 2 cases (Fig. 5). In one of these, an adhesive resin containing 4-META was used as the denture base. However, dye penetration has been detected even in dentures containing 4-META adhesive resin base that usually effectively prevents dye penetration into the finish line of a cast base ${ }^{5)}$. Very frequent thermal cycling processes have been reported to result in considerable loss of adhesiveness between pure titanium and 4-META-containing adhesive resin ${ }^{6}$. These findings strongly suggest the need for further improvements in the adhesiveness between the denture base resin and pure titanium.

Discoloration of pure titanium was found in one case- a brownish color on the plate. This seems to have resulted from the deposition of nicotine caused by smoking, but it could be removed.

Fracture of denture, snapping of the clasp, deformation and other abnormalities were not observed in any of the cases examined. The cast clasps also seemed to maintain enough retentive force. 


\section{Co-Cr:0.35mm}
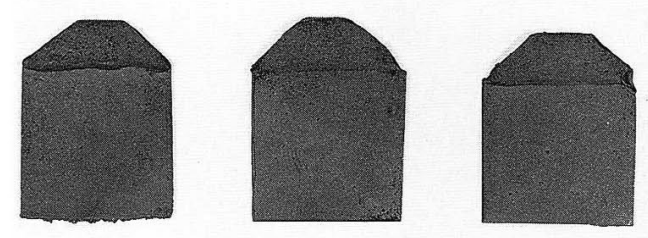

\section{Co-Cr:0.70mm}
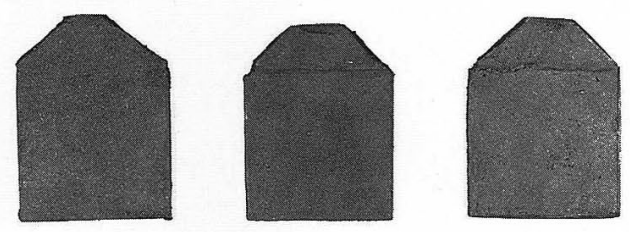

Fig. 7 Casting of the $\mathrm{Co}-\mathrm{Cr}$ alloy in both the $0.35 \mathrm{~mm}$-thick and $0.70 \mathrm{~mm}$-thick wax pattern produced satisfactory casts.

\section{PureTi:Mesh}

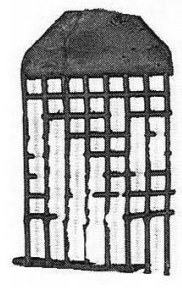

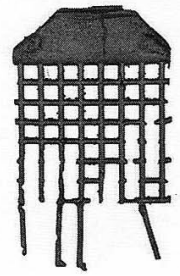

A

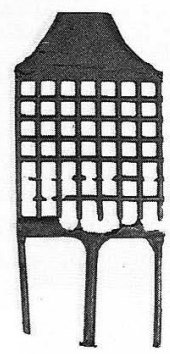

\section{Co-Cr:Mesh}

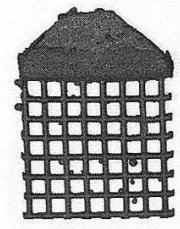

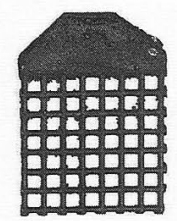

B

Fig. 8 A complete mesh form was not reproduced in casting of pure titanium (A) but was obtained in casting of the $\mathrm{Co}-\mathrm{Cr}$ alloy (B).

Minor, incomplete casting was found in only one case, that was in the casting of the $0.35 \mathrm{~mm}$-thick wax pattern. Casting was perfect in the $0.70 \mathrm{~mm}$-thick wax pattern (Fig. 6). Casting of the $\mathrm{Co}-\mathrm{Cr}$ alloy produced satisfactory casts, regardless of the thickness of the wax patterns (Fig. 7). This suggests that in casting of pure titanium, a somewhat thicker wax pattern is needed than in casting of an ordinary cast denture.

Attempts at casting of pure titanium in the mesh pattern failed to reproduce a perfect mesh cast. However, the $\mathrm{Co}-\mathrm{Cr}$ alloy was cast in complete mesh (Fig. 8). A mesh is used as a retention framework of the cast base and resin. In considering the casting results of pure titanium, a little broader ladder-like or roundish configration, instead of a mesh form, seems better suited as the retention framework for the system used.

$X$-ray inspection of casting defects

X-ray examination of casting defects in the dentures revealed multiple area of casting defects, including very minor, hardly discernible defects. No casting defects were detected at all in only one of the lower partial dentures (Fig. 9).

Lewis $^{7)}$ has found internal porosities in almost all cast, by his X-ray examination of cast partial nonprecious metal alloy dentures. This indicates that it is not in pure titanium alone that internal porosities occur. 


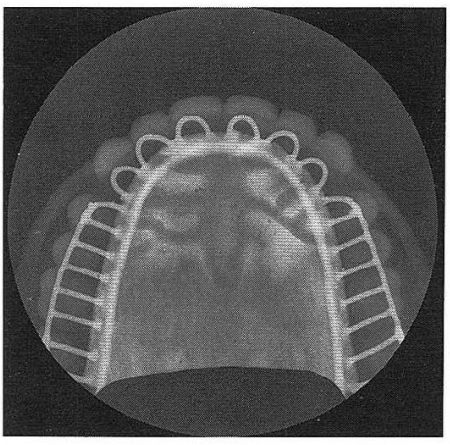

A

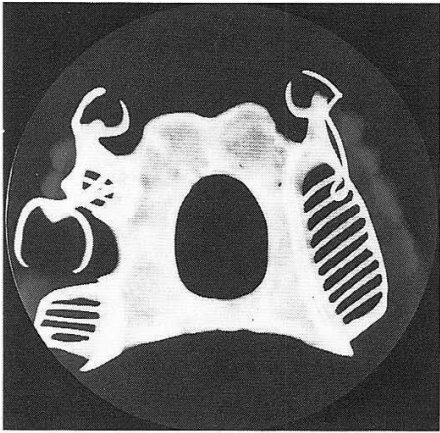

C

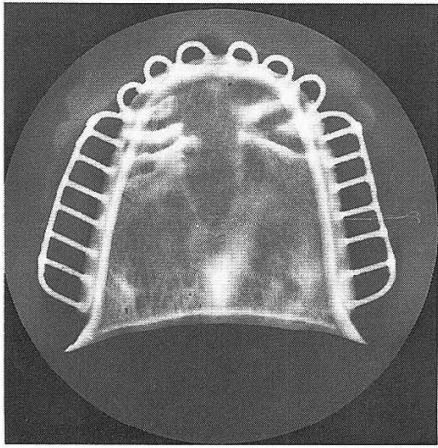

F

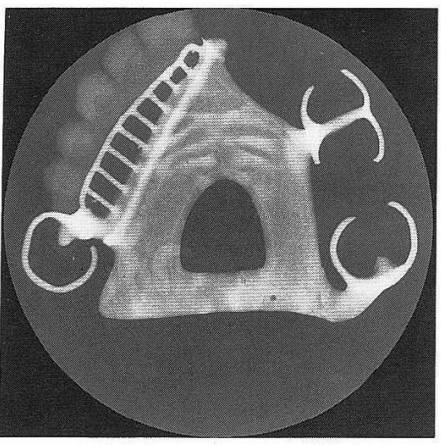

$\mathrm{Bu}$

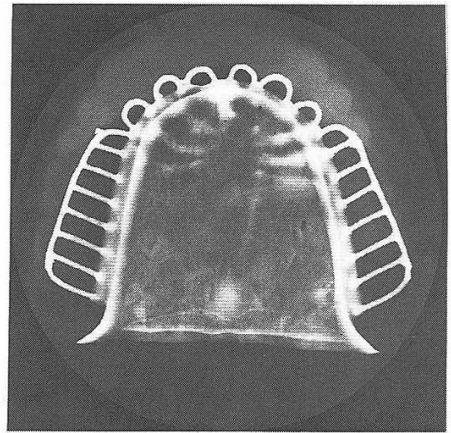

D

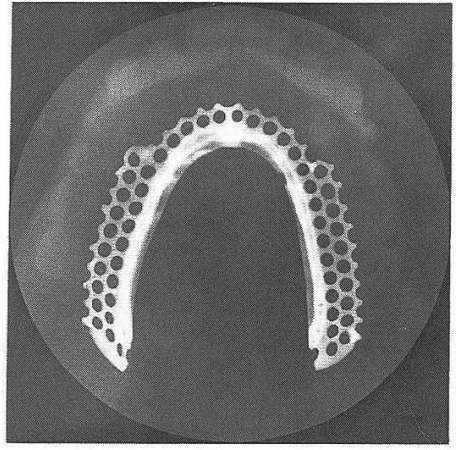

G

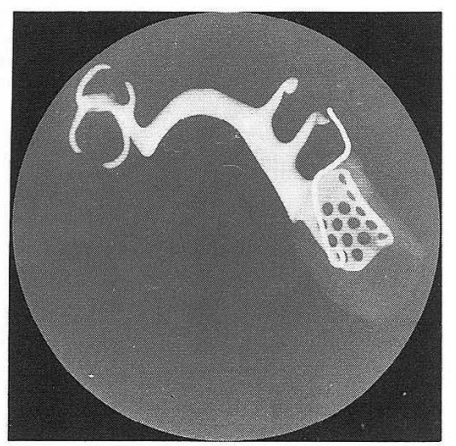

$\mathrm{Bl}$

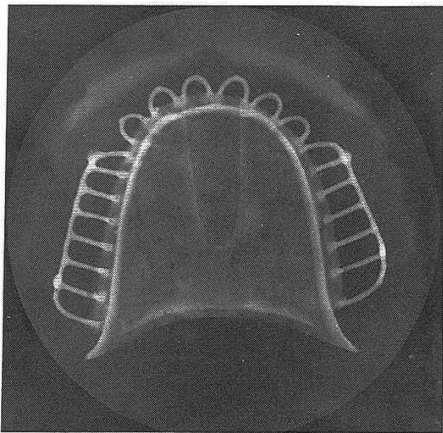

E

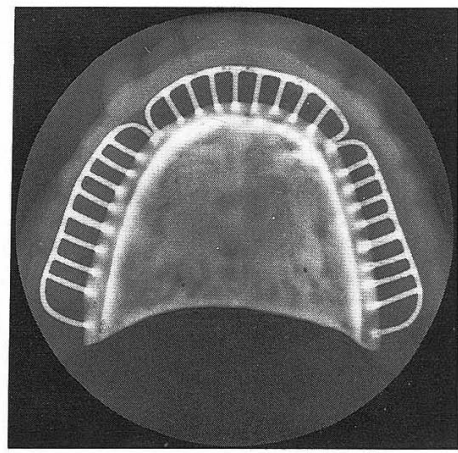

H

Fig. 9 X-ray examination of casting defects in the dentures. Multiple area of casting defects are visible in dentures $\mathrm{D}, \mathrm{E}$, and $\mathrm{H}$. Casting defects are hardly discernible in dentures $\mathrm{A}, \mathrm{Bu}, \mathrm{C} . \mathrm{F}$ and $\mathrm{G}$. Denture $\mathrm{Bl}$ is entirely free from any casting defects.

In the casting experiment of pure titanium, casting defects did not exist in some of the samples cast in both the $0.35 \mathrm{~mm}$-thick and $0.70 \mathrm{~mm}$-thick wax patterns. In samples with casting defects, however, the defects were somewhat larger, compared to those found in the clinical cases (Fig. 10). Casting of the $\mathrm{Co}-\mathrm{Cr}$ alloy resulted in no casting defects in both the $0.35 \mathrm{~mm}$-thick and $0.70 \mathrm{~mm}$-thick wax patterns (Fig. 11). The existence of larger casting 


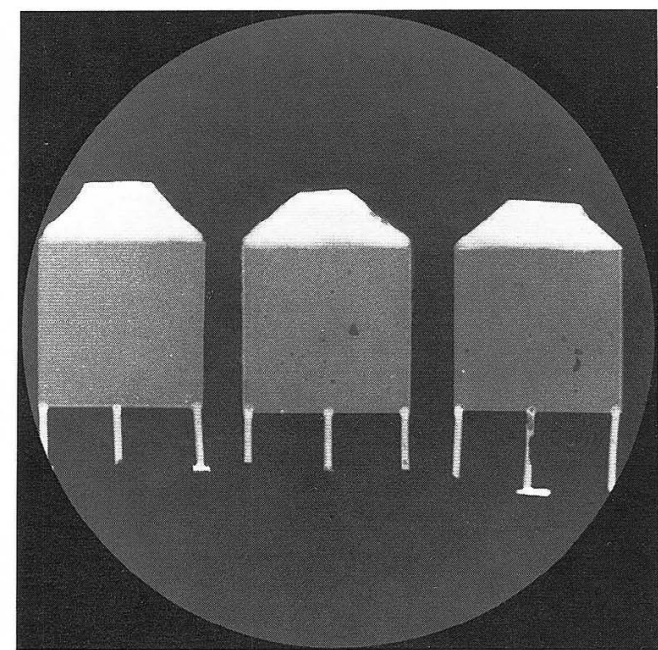

A

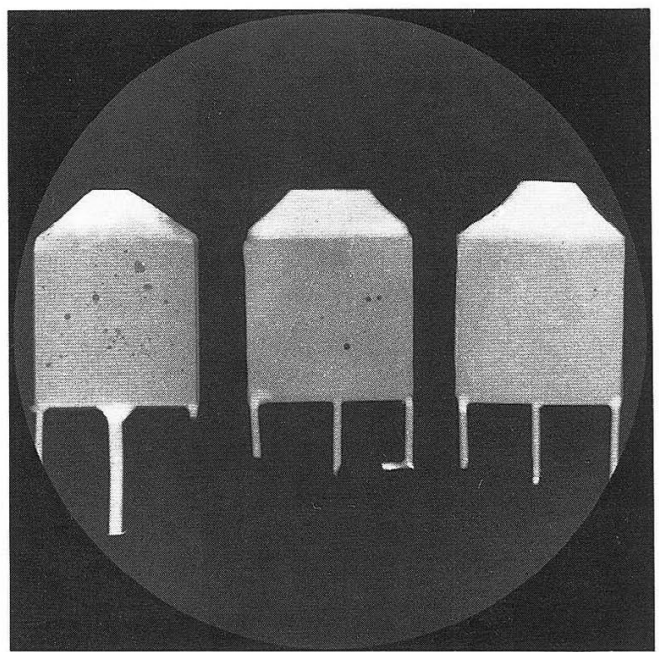

B

Fig. 10 Casting defects are not detected in some of the pure titanium cast samples regardless of the thickness of wax patterns. In Samples with defects, the defects are somewhat larger than those seen in the dentures.

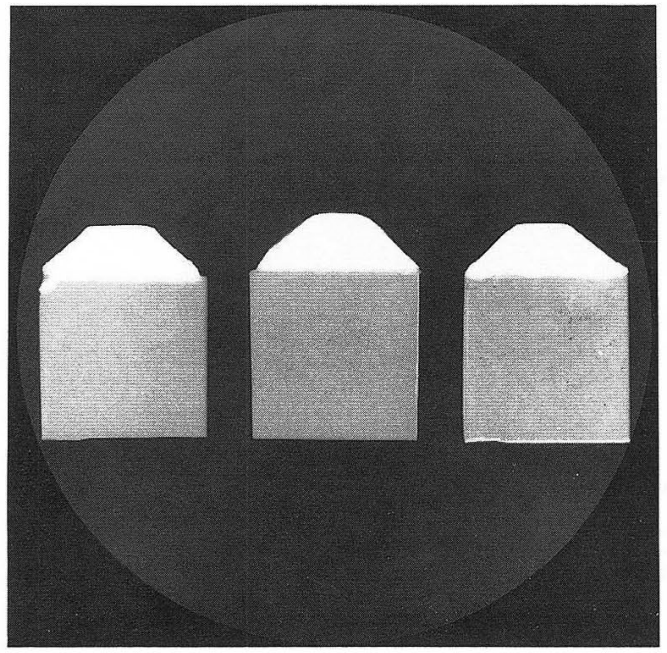

A

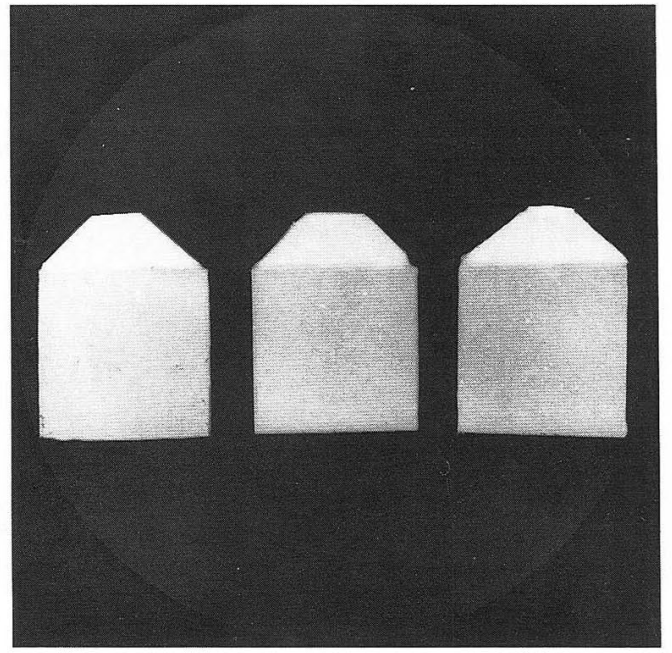

B

Fig. 11 No casting defects were detected in the $\mathrm{Co}-\mathrm{Cr}$ alloy cast samples of both the $0.35 \mathrm{~mm}$-thick and $0.70 \mathrm{~mm}$-thick wax patterns.

defects in the pure titanium casts of plate-type wax patterns than in the clinical cases, may be attributed to the differences in the sprues and vents used in the casting of the dentures fitted to the patients. Judging from the nature of casting defects in the clinical cases, denture fracture seems unlikely to occur in these clinical cases.

The results of the present clinical and technical study indicate that the pure titanium cast plate dentures made by this system contain no problems in clinical application. 


\section{CONCLUSION}

The pure titanium cast plate dentures produced by the commercial pure titanium casting system gave satisfactory fitness. They were free from discoloration and damage, and had a good adaptability to the mucosal surface. Futhermore, they were lighter in weight when compared to conventional cast dentures. X-ray examination revealed some casting defects, but these defects were not serious enough to cause damages. Follow-up observation of patients with these dentures indicated no clinical problems. Inadequate adhesiveness with resin was a technical problem encountered. Examination of the castability of pure titanium using this system showed that casting in the mesh-type wax pattern failed to produce a complete form of mesh, while casting in the plate-type wax pattern produced a complete contour of the plates. X-ray examination of the plate casts, however, revealed some casting defects. These results suggest the necessity of further studies into the details of this study, such as the above-mentioned problem.

\section{REFERENCES}

1) Ida, K., Togaya, T., Tsutsumi, S. and Takeuchi, M. : Effect of magnesia investments in the dental casting of pure titanium or titanium alloys, Dent. Mater. J., 1: 8-21, 1982.

2) Togaya, T., Suzuki, M., Tsutsumi, S., and Ida, K.: An application of pure titanium to the metal porcelain system, Dent. Mater. J., 2: 210-219, 1983.

3) Ida, K., Tani, Y., Tsutsumi, S., Togaya, T., Nanbu, T., Suese, K., Kawazoe, T., Nakamura, M., and Wada, H., : Clinical application of pure titanium crowns, Dent. Mater. J., $4:$ 191-195, 1985.

4) Ida, K. : Dental casting technique for titanium - The present status in Japan and the world-, Quintessence Dent. Tech., 11 : 645-657, 1986. (In Japanese)

5) Mogi, T., : Studies on adhesion of methacrylic resin to cobalt-chromium alloy for denture base Effects of 4- methacryloxyethyl trimellitate anhydride monomer, J. Jpn. Prosthodont. Soc., 23 : 600 -676, 1979. (In Japanese)

6) Matsumura, H., Kojima, K., Kadoma, y. and Masuhara, E. : Studies on dental self-curing resin (26) Effect of 4-META and 4-MET addition to the MMA-TBBO resin, J. J. Dent. Mater., 3: 480-489, 1984. (In Japanese)

7) Lewis, A. J. : Radiographic evaluation of porosities in removable partial denture castings, J. Prosthet. Dent., 39 : 278-281, 1978. 
を作用させない場合の接着強さを測定した。

1-35 (MTYA) を作用させないと，リン酸およびクエ ン酸エッチングの場合，試験体を作製することはできな かった。1-35 (MTYA) を作用させると、リン酸エッチ ングで $18 \mathrm{MPa}$ ，クエン酸エッチングで $23 \mathrm{MPa}$ と接着 強さは大幅に向上した。10-3 エッチングの場合は, 30 秒
エッチングで $16 \mathrm{MPa}, 60$ 秒エッチングで $20 \mathrm{MPa}$ の接 着強さが得られた。

樹脂含浸層の厚さと接着強さとは比例しておらず，樹 脂含浸層の成分が接着強さに大きな影響を与えているこ とが示唆された。

\section{$\mathrm{Be}$ を含む市販陶材焼付用 $\mathrm{Ni}-\mathrm{Cr}$ 合金の}

\section{高温酸化で生じた酸化薄膜の極微分析}

渡辺孝一*, 大川成剛*, 宮川 修*

中野周二*, 塩川延洋*, 小林正義**

*新潟大学歯学部歯科理工学教室

$\mathrm{Be}$ を含む陶材焼付用 $\mathrm{Ni}-\mathrm{Cr}$ 合金上に生成された酸化 薄膜を，ガラス裹打法を用いた EPMA とデバイーシェ ラー粉末 X線回折法により研究した。酸化条件は大気中 で $700^{\circ} \mathrm{C} \cdot 5$ 分間，または $1,000^{\circ} \mathrm{C} \cdot 2$ 分間，あるいは真 空中 $\left(10^{-3}\right.$ Torr $)$ で $1,000^{\circ} \mathrm{C} ・ 40$ 分間といずれも薄い酸 化膜が生じるよう限定されている。大気中における酸化 では $\mathrm{NiO}$ と $\mathrm{Cr}_{2} \mathrm{O}_{3}$ が主要酸化物であり, 後者の前者に

\section{**新潟大学 X線マイクロアナライザー室}

対する比は $700^{\circ} \mathrm{C}$ の場合 0.57 そして $1,000^{\circ} \mathrm{C}$ の場合 2.5 であった。真空中に拈ける酸化では $\mathrm{BeO}$ と $\mathrm{BeCr}_{2} \mathrm{O}_{4}$ だけが検出された。いずれの場合においても，酸化膜の 微細構造は下地となった合金相に対応して変化してい た。これら得られた構造や形態に関するデータについて, 酸化理論を参考にしながら考察した。

\section{純チタン鋳造床の臨床応用 \\ 山内六男, 堺誠, 川野襄二 \\ 朝日大学歯学部歯科補経学第 1 講座}

オハラの純チタン鋳造システムにより製作した純チタ ン鋳造床を 9 名の患者に装着し経過観察を行った。その 結果, 装着感も良く, 破損もなく, 粘膜面との適合性も 良好で，かつ通常の金属床義歯に比べて軽量であつた。 また，X線による鋳造欠陥の検査では多少の鋳造欠陥が 認められたが金属床の破損を引き起こすようなものでは ないと考えられた。これらの臨床的観察結果からみて臨 床応用上問題となる点はないと考えられた。ただし，床
用レジンとの接着性が弱いこと，本システムによる純チ タンの鋳造性についての実験では,メッシュパターンの 場合,メッシュが完全に鋳造されないこと,平板のパター ンの場合輪郭的には鋳造されていてもX線による鋳造欠 陥の検査では若干鋳造欠陥が認められたことなどから， 今後この点を含めより詳細な検討が必要であることが示 唆された。

\section{小窩裂溝填塞材の硬化特性}

藤井孝一*，奥 淳一*，有川裕之**, 山内浩人**

大野秀夫***, 小椋 正 $^{* * *}$, 井上勝一郎*

*鹿児島大学歯学部歯科理工学講座

***長崎大学歯学部小児歯科学講座
**鹿児島大学歯学部第一補綴学講座

*鹿児島大学歯学部小児歯科学講座 